mical forces scem to have often a larger share in the effects; this appeared most distinctly in the remarkable absorbing power of hydrated iron oxide, and soils containing most of it ; which can only be attributed to chemical changes undergone on access of gases, in consequence of the easy decomposition of the constituents. The same holds good for humus materials; whereas with the other constituents the physical "moment" comes out more prominently. Those gases which are easily brought into the liquid state $\left(\mathrm{H}_{2} \mathrm{O}, \mathrm{H}_{2} \mathrm{~S}, \mathrm{CH}_{4}, \mathrm{NH}_{3}\right.$, and $\left.\mathrm{CO}_{2}\right)$, and which undergo changes easily $\left(\mathrm{NH}_{3}, \mathrm{SH}_{2}\right)$, are absorbed in greater measure by the constituents of soils, than gases which are not readily liquefied $(O)$. Temperature has great influence; with increase of it the power of condensing gases diminishes. It is notable that at temperatures between $0^{\circ}$ and $10^{\circ}$ the gas absorption again diminishes. (A fuller account of these researches will be found in Der Naturforscher for March . 15.)

ANOTHER new Italian journal has come to hand, Vita Nuova, published fortnightly. It is devoted to literature, science, and art, and the scientific notes seem to us to be done with care and discrimination, containing occasional information on scientific work in Italy. It is published at Padua.

THE Colonies and India states that excellent accounts have been received from Tasmania. Stone exceedingly rich had been discovered in the Alpine reef, Fingal district, estimated to yield 200 ounces of gold to the ton. Gold had also been discovered at Castray River in the North Meredith Range on the west coast.

MM. Figuier and de Parvilie have issued their Année Scientifuque, which is a summary of all the notable discoveries made during the past year.

THE additions to the Zoological Society's Gardens during the past week include a Black-backed Jackal (Canis mesomelas) from South Africa, presented by Mr. E. J. Redman; a Red and Yellow Macaw (Ara chloroptera) from South America, two Yellow-fronted Amazons (Chrysotis ochrocephala) from Guiana, presented by Mrs. Kelly; two Silver Pheasants (Euplocamus nycthemerus) from China, presented by Mr. W. Soper; two Bernicla Geese (Bernicla leucopsis), two Brant Geese (Bernicla irenta), a Bean Goose (Anser segetum), two Common Geese (Anser domesticus), two Ruddy Sheldrakes (Tadorna rutila), two Common Pintails (Dafila acuta), two Gadwalls (Anas strepera), four Chiloe Widgeons (Mareca chiloensis), two Common Widgeons (Mareca penelope), two Garganey Teal (Querquedula circia), two Common Teal (Querquedula crecca), European, four Canada Geese (Bernicla canadensis), a Summer Duck (Alx sponsa) from North America, two Mandarin Ducks (Aix galericulata) from China, three Australian Wild Ducks (Anas superciliosa) from Australia, a Wild Goose (Anser ferus), three Common Ducks (Anas boschas), British Isles, presented by Mr. R. J. Balston, F.Z.S.; a Tuberculated Lizard (Igzana tuberculata) from Trinidad, presented by Dr. J. F. Chittenden, C.M.Z.S.; two Mississippi Alligators (Alligator mississippiensis) from the Mississippi, presented by Lord Francis Conyngham, M.P., F.Z.S.; a Common Lobster (Astacus vulgaris), British Seas, presented by Mr. R. J. Milestone ; two White-rumped Roe Deer (Capreolus pygargus) from Eastern Asia, a Chimese Water Deer (Hydropotes inermis) from China, received in exchange; two Common Boas (Boa constrictor) from South America, deposited; eight Indian Jerboa Rats (Gerbillus indicus) from India, purchased.

\section{VIRCHOW ON THE PLAGUE}

$A \mathrm{~T}$ a recent meeting of the Medical Society of Berlin Prof. Virchow gave (by previous request) his views on the sub. ject of the Plague of Astrakan. The following is a brief outline of his address (which appears in the Revue Scientifique) :-
The information received abont the plague is very uncertain and conflicting, necessitating reserve in giving an opinion. Ruscia is to be reproached for failure to send competent observers of the disease.

The first question is, What is the true determinant of the malady? No one would hesitate to say that the buboes, or swellings of the lymphatic glands, take the first place. But it is still doubtfil whether or not certain acute forms occur without glandular tumour. (It is not merely the exterior glands that are referred to.) Typhoid fever, the most nearly related disease, is, of course, always (except in children) marked by a peculiaraffection of the glands.

The pestilential bubo, like the alterations characterising many of our indigenous infectious diseases, consists in a cellular hypertrophy, with more or less hyperæmia and hæmorrhage. We come again to an obscure point in asking, how does a bubo of this kind ulcerate? The ulcerations in typhoid fever show sup. puration, within the glandular tissue, round a dry mortified centre. Accounts by some of the best observers of pestilential bubo affirm suppuration round the gland. But the chief point is, what is the prime cause of the suppuration? And here I cannot affirm that the abscess of the gland arises from mortification of the gland. Some observers speak only of a softening of the substance. If partial mortification induced the ulcerations distinguishing plague, as they do those of typhoid fever, the analogy between the two diseases would be more marked.

Though we do not really know whether glandular affections are, from the outset, an essential character of the disease, they yet present the essential criteria for diagnosis of the plague.

[Prof. Virchow proceeds to object to Hirsch's view regarding the Indian Flague of $\mathrm{Pali}$, in 1838 , which showed peculiar symptoms, as a particular species of plague. Either it was the plague or it was not the plague. If the malady of Astrakan were a peculiar Indian plague we should not be warranted in identifying it with the well-known plague of the Levant, for this alone is the true plague. Hæmorrhage of the urinary organs (as in the plague of Pali) is very common even in the Oriental plague; but he would not therefore create a special hæmaturic species of the plague, but say that hæmaturia is often a symptom of the plague. He does not now refer either to this plague of Pali nor to a known endemic plague, restricted to two districts of the Himalayas.]

Another special character of Oriental plague is carbuncle ; it occurs in nearly a fifth of the cases; the symptoms are like those of ordinary contayious carbuncle. There is no sufficient evidence of carbuncle in internal organs. Then there are the petechix; or spots, and interior hæmorrhages. Tumour of the spleen seems very constant, and of great importance, and we find also tumefaction of the liver and kidneys. The swellings of the glands, the carbuncles, and the petechiæ are the most important symptoms.

At the beginning of most pestilential epidemics a Committee of doctors has generally declared that it was not the plague. They pronounced it petechial typhus. This was the case imme diately before the outbreak of the plague at Rescht, when the disease had been long confined in Kurdistan and Mesopotamia. M. Tholozan was the first to say it was plague, and that the case was that, not of a great epidemic, but of a latent disease, spreading slowly and attacking only a few. It is indubitable that we have there a true centre, whence the disease gradually spread, and I do not see why we should go to India, where the disease has not prevailed for many years past. Proceeding logi. cally, we shall accept this course: From Kurdistan and Mesopotamia to Persia and on to beyond the Caspian. Even if the present cases on the other side of the Caspian were accompanied by pneumorrhagia, I would not hesitate to say they belonged to the plague proper, and that the disease is the same as that in Mesopotamia. The symptoms are very different from those of petechial typhus, the disea-e which the Turkish doctors affirmed. If near Salonichi (Xanthi) there be really petechial typhus accompanied by Metasiasis bubonica, I fear it is the plague. It remains to keep our eyes open and see what happens after the return of the Russian army from the infected country (an occurrence which may well rouse grave apprehensions).

What has been done for our protection is little apt to tranquillise us. A blockade comprising all the frontier as well as the coast, from the Baltic to the Black Sea, seems to me illusory.

One example of severe quarantine has occurred in this century in the case of the plague at Noja, in Bari (Kingdom of Naples), in $18 \times 5$. Trenches were dug, and three cordons of sentinels were 
formed (the third round the entire province), with orders to kill whoever tried to break the blockade and did not stop at the first summons; and some individuals were actually killed. But I cannot think an entire country is able to protect itself thus. Examination of passports would be excellent if those who deliver passports and certificates of health were angels. But the Russian functionaries are men, and think like men. The impossibility of always getting true certificates of origin has been seen in the case of the cattle plague. I consider, however, that pressure should be exerted on Russia to form a blockade of the infected districts. And especially it should be seen to, that the returning Russian army does not bring any pestilential germs with it. As to restrictions on communications by land, the greatest it. As to restrictions on communications

I cannot give an opinion as to whether the matters which are now forbidden to be imported into the German Empire may propagate the plague. The negative does not seem to suffice. We know that the skin or hair of an ox affected with carbuncle may engender contagion after several months in distant countries; we should not forget this, and we have not the right to say that garments, linen, bedclothes, \&c., are perfectly innocuous.

A word on two points relative to disinfection. On Prof. Pettenkofer's advice, the German empire has decided for sulphurous acid as a means of disinfection. I question if this substance would penetrate linen, clothes, wool, \&c., in such a complete way as to annihilate all germs. In my opinion a better plan is disinfection of clothing, \&c., by dry heat in a chamber surrounded by steam-pipes, the temperature being raised to $120^{\circ} \mathrm{C}$. or more. This plan is more ratio nal and easy, and damages the objects least.

\section{UNIVERSITY AND EDUCATIONAL} INTELLIGENCE

IN the Cambridge Senate, last Saturday, Mr. Balfour, a recent examiner in the Natural Science "Specials" for the B.A. degree, spoke of the schedule for botany, to which we referred recently, as extremely unsatisfactory and incomplete; histology was altogether neglected; physiology was very unsatisfactorily dealt with, and cryptogamic botany was almost entirely omitted. He was in favour of an examination in elementary biology being substituted, and practical work being required. Physiology should be made a separate subject. Prof. Humphry spoke in favour of reducing requirements in schedules to the narrowest ran re, in order to make natural science attractive to men. Mr. Trotter thought the schedule in botany an absurdly small representative of a year's work for a man supposed to have no other definite study. $\mathrm{Mr}$. Bettany found fault with the present constitution of the Board of Natural Science Studies, which dealt with too many subjects, each being insufficiently represented by men engaged in teaching and research. No doubt it is hard for many to realise that biology has very many distinctive aspects, each of which must be represented by proficiency in them to prevent injustice and injury to scientific progress. Hindrances also arise from the fact that many of our present leaders and directors of study were developed before the full recosnition of cell-study, embryology, and the like, as the basis of sound biology.

Dr. Alexander Dixon, Professor in the University of Glasgow, has been elected to the Professorship of Botany in the University of Edinburgh, vacant by the resignation of Dr. Balfour.

\section{SCIENTIFIC SERIALS}

The Archives des Sciences Physiques at Naturelles (February, 1879), contain the following papers of interest:-On the hydrocarbons obtained through the action of methyl-chloride upon benzole in the presence of ammonium chloride, by MM. E. Ador and A. Rillet.-.On the theory of timbre and particularly on that of vowels, by Dr. Schneebeli.--On the scientific principles of the fine arts; essays and fragments on the theory, by $\mathrm{E}$. Brucke, followed by remarks on optics and painting, by $\mathrm{H}$. Helmholtz. -On some rare mosses, by J. E. Duby.-Stratigraphical study of the south-western part of the Crimea, by E. Favre.-Natural history of batrachia, by Fr. K. Knauer.-On apogamic ferns and on apogamy generally, by Prof. A. de Bary.-On the prolification of the firuit of mosses, by Dr. N. Pringsheim. - On poly embryony, by Dr. Ed. Strasburger.
THE Fournal de Physique (March) contains the following more important papers :-On spectroscopes with direct vision and great dispersion, by M. Thollon.--On the logograph, by M. Barlow. - On a new phenomenon of static electricity, by M. E. Duter. -Note on spectrophotometers, by M. A. Crova.- On the vibratory motion generated in the air and in space by electric sparks, by E. Mach. - On the electricity of air, by Rob. Nahrwold.

\section{SOCIETIES AND ACADEMIES}

\section{LONDON}

Royal Society, March 13.- "On the Influence of Coal-dust in Colliery Explosions." No. 2. By W. Galloway. Communicated by Robert H. Scott, F.R.S., Secretary to the Council of the Meteorological Office.

The first experiment is made with a very simple apparatus consisting of a continuous pipe about $18^{\prime \prime}$ in diameter, which conducts a small portion of the return air from the point at which it is ejected into the atmosphere by the ventilating fan, to a convenient spot on the level of the surface, where it escapes as a strong current, amounting to I,25I cubic feet per minute. About 6 feet from its point of exit a lamp can be placed in the centre of the current, and at a distance of about a foot still nearer the origin there is a means of allowing coal-dust to fall into and mix with the passing air. It is found that when the coal-dust is added the air becomes instantly inflammable, showing that all the return air in the workings may be easily brought into the same condition by a sudden disturbance such as that caused by a local explosion of fire-damp.

The second experiment is intended to illustrate the effects of an explosion of fire-damp in a dry mine containing coal-dust. One part of the apparatus represents a gallery with coal-dust lying on its floor as well as in the horizontal timbers, the buildings and other rough surfaces at its top and sides; another part represents a cavity in the roof containing an explosive mixture of fire-damp and air. When the explosive gas is ignited the flame sweeps down into the gallery, the disturbance raises the coal-dust, and the results are exactly those that have been foreseen. The gallery is a wooden pipe 14 inches square inside, by $79 \frac{1}{2}$ feet long. The explosion-chamber is a sheet-iron cylinder lined with thin wooden laths; it is 5 feet high by 15 inches in diameter, and it stands vertically on the top of the gallery at a distance of 5 feet from one end. Currents of air of different quality can be made to pass along the gallery from the end next the explosion-chamber, which can be isolated by means of a valve, to the other end which is open to the atmosphere; thus the return air of the mine can be made to traverse it, or a current of pure air, or a current of air mixed with any required propor-. tion of fre-damp. At the point where they enter the gallery these air-currents are heated by a steam cylinder, which occupies part of the space between the explosion-chamber and the nearer end, so as to assimilate their temperature to that of the air in a mine. The coal-dust is spread along the floor of the gallery, and some is laid on shelves so that it may more easily mix with the air when it is disturbed.

The explosive mixture is made by admitting about half a cubic foot of fire-damp into the explosion-chamber at its upper end, while a corresponding quantity of air is allowed to escape through a plug-hole at its lower end. The bottom of the explosion-chamber is separated from the gallery by a diaphragm of paper during this part of the operation. After the requisite quantity of fire-damp has been admitted, its volume having been accurately measured so as to guarantee that the results will always be the same, the mixture is effected by rapidly revolvin a small fan, situated at the top of the explosion-chamber, and so constructed as to draw in air from the centre of the chamber, and throw it out at the circumference. From the point at which the fan draws in its air a 4 -inch pipe descends to near the bottom of the explosion-chamber, and when the fan is revolved the air is drawn up through this pipe and discharged at the top of the chamber, from which it finds its way again to the bottom, and so on. The circulation established in this way is so rapid that a perfect mixture can be made in half a minute. The explosive mixture is ignited by means of a spark from a powerful magnetoelectric machine.

When there is no conl-dust in the gallery the flame of the firedamp explosion does not extend further than from 7 to 9 feet from the bottom of the explosion-chamber. 